\title{
Understanding sciatica: illness and treatment beliefs in a lumbar radicular pain population. A qualitative interview study
}

\author{
Robert Goldsmith, BSc, MSc, MMACP ${ }^{1 *}$, Nefyn Howard Williams, PhD, FRCGP2, \\ Fiona Wood, MSc, PhD ${ }^{3}$
}

${ }^{1}$ Advanced Physiotherapy Practitioner, Bangor University and Cardiff and Vale University Health Board, Cardiff, UK; ${ }^{2}$ Professor in Primary Care, University of Liverpool, Liverpool, UK; ${ }^{3}$ Reader, Division of Population Medicine, Cardiff University, Cardiff, UK

*For correspondence: robert. goldsmith@wales.nhs.uk

Competing interest: The authors declare that no competing interests exist.

Received: 21 May 2019

Accepted: 23 May 2019

Published: 07 August 2019

(C)This article is Open Access: CC BY license (https://creativecommons.org/licenses/by/4.0/)

Author Keywords: Sciatica, Low back pain, Radicular pain, Illness beliefs, Qualitative research, Primary health care, Treatment beliefs

Copyright (C) 2019, The Authors; DOI:10.3399/

bjgpopen19X101654

\begin{abstract}
Background: Several pathological processes contribute to lumbar radicular pain (LRP), commonly known as sciatica. It is not known how patients rationalise the experience of sciatica or understand the diagnosis. Providing clinicians with a better understanding of how patients conceptualise sciatica will help them to tailor information for patients on the management and treatment of the condition.
\end{abstract}

Aim: To understand patients' beliefs regarding their illness following a diagnosis of LRP, how these beliefs were developed, and the impact of illness beliefs on treatment beliefs.

Design \& setting: Qualitative interview study from a single NHS musculoskeletal interface service (in Wales, UK).

Method: Thirteen patients recently diagnosed with LRP were consecutively recruited. Individual semistructured interviews were recorded and transcribed. Data were analysed using a thematic approach.

Results: Four main themes were generated: (1) the illness experience (2) the concept of sciatica, (3) treatment beliefs, and (4) the desire for credible information.

Conclusion: The diagnosis of LRP is often communicated and understood within a compressive conceptual illness identity. Explaining symptoms with a compressive pathological model is easily understood by patients but may not accurately reflect the spectrum of pathological processes known to contribute to radicular pain. This model appears to inform patient beliefs about treatments. Clinicians should take care to fully explain the pathology prior to shared decision-making with patients.

\section{How this fits in}

LRP (sciatica) is often explained and understood as being caused by nerve compression. While this is often part of the pathological process, inflammation and neural sensitisation play important roles. Explaining radicular pain in terms of compression alone may influence treatment decisions and leave patients with no evidence of compression without an explanation for their pain. Clinicians should take care to include the roles of inflammation and sensitisation within their discussion of radicular pain pathology. 


\section{Introduction}

Commonly known as 'sciatica', LRP is a painful and disabling condition, resulting in worse pain, disability, and quality of life, and increased use of health resources compared with low back pain alone. $^{1}$

Repeated findings have challenged the adequacy of the pathoanatomical model to fully explain LRP pathology. Although LRP is often caused by an intervertebral disc prolapse, ${ }^{2}$ nerve root compression is commonly seen in asymptomatic populations. ${ }^{3}$ Serial imaging is only able to demonstrate a 'new' compression in 3\%-7\% of incident radicular symptoms. ${ }^{4}$ Furthermore, the degree of neural compression does not correlate with symptoms ${ }^{5}$ or recovery. ${ }^{6,7}$ Approximately $67 \%$ of disc herniations will spontaneously reabsorb, but symptoms may persist. ${ }^{8}$

Although LRP can arise from mechanical compression of the nerve root (causing hypoxic damage), the presence of pro-inflammatory material from the disc is required to sensitise nerve roots. ${ }^{9,10}$ Mechanical stimulation of nerve roots that have not been exposed to inflammation does not cause radicular pain. ${ }^{11}$ Conversely, radicular pain has been observed without compression. ${ }^{12,13}$ There is increasing evidence that radicular pain may involve almost all types of pain, including ischaemic, inflammatory, mechanical, and neuropathic pain. ${ }^{14}$

Despite this complexity, the natural history of LRP is generally considered to be favourable, with estimates of $60 \%$ achieving a good outcome ( $\geq 30 \%$ improvement in disability) by 3 months and $55 \%-$ $70 \%$ by 1 year. ${ }^{7,15}$ During this time period, there can be significant impact on the individual, with LRP perceived to be 'constant, intense, and all-encompassing'. ${ }^{16}$

Ong et ${ }^{1}{ }^{16}$ explored patient beliefs in a 'sciatica' population. The identification of a cause (such as an event or behaviour) and the use of medical terms to describe and legitimise their pain were important to people because they provided an explanation of why they were in pain. ${ }^{16}$

The Common Sense Model (CSM) of self-regulation ${ }^{17}$ is a framework for understanding illness perceptions. The CSM explores patient perceptions of cause, prognosis, consequences, and treatment effectiveness. The model assumes that as people obtain new information about their condition and evaluate their attempts to moderate or cope with its effects, illness representations are formed and thereafter continually refined. ${ }^{17}$ The process of refining illness representations is influenced by personal experience as well as the opinions of significant others, health professionals, and media sources. ${ }^{18,19}$ Illness representations have been correlated with maladaptive coping, self-efficacy, anxiety, depression, and quality of life in other clinical populations. ${ }^{20,21}$ The CSM assumes that people aim for coherence between illness representations and treatment beliefs, matching treatment decisions to their illness. ${ }^{22}$ Previous reviews have recommended that researchers consider the combined role of both illness and treatment beliefs in physical illnesses. ${ }^{23}$

The aim of this study was to understand patients' conceptual beliefs of sciatica and what might influence their development, using the illness identity component of the CSM. The authors sought to understand how illness representations might influence perceptions of different treatment options.

\section{Method}

\section{Participants and recruitment}

The setting was a musculoskeletal triage service in a Welsh NHS health board serving a mixed urban and suburban adult population of approximately 400000 people. ${ }^{24}$ Participants were referred to the service by their GP, and were aged $\geq 18$ years, with symptoms for more than 4 weeks and a clinical diagnosis of radicular pain (Box 1). After their usual care, eligible candidates were approached by their clinician, an advanced physiotherapy practitioner. Participants were consecutively sampled for a homogenous diagnosis according to the criteria for LRP, ${ }^{25,26}$ between January-September 2018. A total of 36 recruitment packs were given out. Reasons for non-participation are not known. Of those participants who responded to the recruitment information, one was excluded (due to bilateral leg pain), and the remaining 13 participants completed the study. 
Participants were excluded if they reported bilateral leg pain, cauda equina symptoms, or there was clinical suspicion of sinister pathology. Additional exclusion criteria included inability to speak English, a lack of capacity for informed consent, or any prior contact with the researcher. Potential participants were given written information regarding the study and asked to return a reply slip to the research team if they were interested in contributing.

\section{Data collection}

An interview guide was developed using items from the Illness Perception Questionnaire (IPQ) ${ }^{27}$ and Low Back Pain Treatment Beliefs Questionnaire (LBP-TBQ), ${ }_{i}^{22}$ further information is available from the authors on request. Open questions were used to prompt reflection and discussion, and the interviewer reflexively explored emergent issues as they developed.

Care was taken to minimise researcher bias throughout the data collection and analysis cycle. The interviewer (a male advanced physiotherapy practitioner with $>10$ years clinical experience, and an MSc in Physiotherapy), received 3 days of specialist training in conducting qualitative interviews. The research team also included a GP and social scientist, which ensured a range of perspectives and helped the researchers check each other's assumptions. Prior to data collection, the interviewer documented his assumptions and biases regarding radicular pathology and its management (these included a belief in the importance of patient education, shared decision-making, and the limitations of magnetic resonance imaging [MRI] findings to explain symptoms). Three practice interviews were also conducted, and feedback was sought. The interviewer identified himself to participants as a researcher who was interested in patients' understanding of their condition.

To put participants at ease, the one-to-one interviews were conducted either in the participant's own home or in a quiet room within a hospital, separated from the physiotherapy department (participants chose which location).

Individual, in-depth, face-to-face interviews were audiorecorded and transcribed verbatim. Participants chose pseudonyms to maintain anonymity. In order to minimise bias and maximise the richness of responses, field notes were kept reflecting on interview performance and style. Analytical memos of emergent content were recorded.

To inform judgments of transferability, participants completed a demographic questionnaire, the Tampa Scale of Kinesiophobia, ${ }^{28}$ and the Modified Rolland Morris Disability Scale ${ }^{29}$ before the interview. The questionnaires were chosen as illness beliefs have been associated with disability and fear of movement. ${ }^{30,31}$

Recruitment was continuously reviewed for information power and level of saturation by the lead author, in discussion with other team members. A consensus judgment that sufficient saturation had taken place was achieved when data were available for each of the nine initial a priori codes, and no new codes or themes were emerging from the data. After the 11th interview, the interviewer felt that he was hearing repetition of previous data with no new insights or themes being developed (informational redundancy). ${ }^{32}$ Data from two further interviews were collected, and it was confirmed that no new themes were emerging. Although the sample size may appear relatively modest, the interviews were found to have significant 'information power', sufficient to allow in-depth analysis. ${ }^{33}$

\section{Data analysis}

The lead author familiarised himself with the data before initially coding all interviews using NVivo (version 12) software. In order to achieve a balance between within- and across-case analysis, emergent themes were identified and reviewed using a template analysis approach. ${ }^{34}$ An initial a priori coding template was developed using terms derived from the illness dimensions of the IPQ (identity, consequences, timeline, control/cure and cause), and the treatment dimensions from the LBP-TBQ (credibility, effectiveness, concerns, and individual 'fit'). This coding framework was refined during the analysis, with a priori codes being redefined, deleted, or replaced with codes emerging from the data to form a final coding template. To ensure the analysis remained sensitive to uncovering the beliefs, attitudes, and values of individual participants, a 'one sheet of paper' analysis ${ }^{35}$ for each participant was performed to create additional conceptual themes and contexts. Themes were continually reviewed and refined throughout analysis. Member-checking and participant feedback on themes were not used as it was considered too onerous on the participants. 
Table 1 Participant characteristics

\begin{tabular}{|c|c|c|c|c|c|c|c|c|c|}
\hline $\begin{array}{l}\text { Alias, age, } \\
\text { sex }\end{array}$ & $\begin{array}{l}\text { Occupation and work } \\
\text { status }\end{array}$ & Symptoms & Duration & Course & Imaging & $\begin{array}{l}\text { Treatments } \\
\text { received }\end{array}$ & RMDQ & TSK & $\begin{array}{l}\text { Management } \\
\text { plan }\end{array}$ \\
\hline Edward 71, M & Retired & Leg pain & 40 years & $\begin{array}{l}\text { Episodic (not } \\
\text { in an episode } \\
\text { at the time of } \\
\text { interview) }\end{array}$ & MRI & $\begin{array}{l}\text { Medication, } \\
\text { acupuncture, } \\
\text { chiropractic, } \\
\text { physiotherapy }\end{array}$ & $1 / 24$ & 32 & $\begin{array}{l}\text { Self- } \\
\text { management }\end{array}$ \\
\hline Myfanwy, 53, F & $\begin{array}{l}\text { Police officer; on sick leave } \\
\text { due to symptoms }\end{array}$ & $\begin{array}{l}\text { Leg pain > } \\
\text { back pain }\end{array}$ & 8 months & Episodic & MRI & $\begin{array}{l}\text { Medication, } \\
\text { chiropractic, } \\
\text { physiotherapy, } \\
\text { spinal injection }\end{array}$ & $11 / 24$ & 41 & $\begin{array}{l}\text { Review with } \\
\text { APP }\end{array}$ \\
\hline Gordon, 57, M & $\begin{array}{l}\text { Delivery driver; } \\
\text { unemployed; stopped work } \\
\text { due to symptoms }\end{array}$ & Leg pain & 10 months & $\begin{array}{l}\text { Severe, } \\
\text { constant }\end{array}$ & $\begin{array}{l}\text { XR } \\
\text { MRI }\end{array}$ & Medication & $22 / 24$ & 43 & Physiotherapy \\
\hline Gethin, 42, M & Employed & $\begin{array}{l}\text { Leg pain> } \\
\text { back } \\
\text { pain, foot } \\
\text { numbness }\end{array}$ & 1 year & $\begin{array}{l}\text { Constant, not } \\
\text { changing }\end{array}$ & MRI & Osteopathy & $14 / 24$ & 33 & $\begin{array}{l}\text { Physiotherapy } \\
\text { and review } \\
\text { with } \\
\text { consultant }\end{array}$ \\
\hline Marley, 52, M & $\begin{array}{l}\text { Self-employed, runs own } \\
\text { training company }\end{array}$ & Leg pain & 3 years & $\begin{array}{l}\text { Constant, } \\
\text { variable }\end{array}$ & MRI & $\begin{array}{l}\text { Medication, } \\
\text { osteopathy, } \\
\text { physiotherapy, } \\
\text { spinal surgery }\end{array}$ & $3 / 24$ & 23 & $\begin{array}{l}\text { Nerve root } \\
\text { block } \\
\text { 土surgical } \\
\text { opinion }\end{array}$ \\
\hline Ricardo, 45, M & $\begin{array}{c}\text { Engineer; } \\
\text { occasional days off }\end{array}$ & $\begin{array}{l}\text { Leg pain } \\
>\text { back } \\
\text { pain, foot } \\
\text { numbness }\end{array}$ & 2 years & Deteriorating & MRI & $\begin{array}{l}\text { Medication, } \\
\text { acupuncture, } \\
\text { physiotherapy }\end{array}$ & $16 / 24$ & 48 & $\begin{array}{l}\text { Surgical } \\
\text { opinion }\end{array}$ \\
\hline Margret, 76, F & Retired & Leg pain & 3 months & Improving & $\mathrm{XR}$ & $\begin{array}{l}\text { Medication, } \\
\text { physiotherapy }\end{array}$ & $5 / 24$ & 32 & $\begin{array}{l}\text { Self- } \\
\text { management }\end{array}$ \\
\hline Maria, 63, F & $\begin{array}{c}\text { Employed carer; off work } 3 \\
\text { months }\end{array}$ & $\begin{array}{l}\text { Leg pain }> \\
\text { back pain }\end{array}$ & 9 months & $\begin{array}{l}\text { Variable, but } \\
\text { improving } \\
\text { overall }\end{array}$ & $\begin{array}{l}\text { XR } \\
\text { MRI }\end{array}$ & $\begin{array}{l}\text { Medication, } \\
\text { acupuncture, } \\
\text { chiropractic, } \\
\text { physiotherapy }\end{array}$ & $17 / 24$ & 45 & $\begin{array}{l}\text { Nerve root } \\
\text { block }\end{array}$ \\
\hline Megan, 21, F & $\begin{array}{c}\text { Student and works in a } \\
\text { supermarket }\end{array}$ & Leg pain & 8 months & $\begin{array}{c}\text { Severe, } \\
\text { constant, } \\
\text { deteriorating }\end{array}$ & MRI & $\begin{array}{l}\text { Medication, } \\
\text { chiropractic, } \\
\text { physiotherapy }\end{array}$ & $20 / 24$ & 43 & $\begin{array}{l}\text { Surgical } \\
\text { opinion }\end{array}$ \\
\hline Harry, 44, M & $\begin{array}{c}\text { Civil servant; intermittent } \\
\text { time off }\end{array}$ & Leg pain & 18 years & $\begin{array}{c}\text { Episodic, } \\
\text { deteriorating }\end{array}$ & MRI & $\begin{array}{c}\text { Medication, } \\
\text { chiropractic, } \\
\text { physiotherapy, } \\
\text { nerve root } \\
\text { block }\end{array}$ & $18 / 24$ & 45 & $\begin{array}{l}\text { Review with } \\
\text { consultant }\end{array}$ \\
\hline Patricia, 68, F & Retired & $\begin{array}{l}\text { Leg pain and } \\
\text { numbness }\end{array}$ & 5 months & Improving & $\begin{array}{l}\text { XR } \\
\text { MRI }\end{array}$ & $\begin{array}{l}\text { Medication, } \\
\text { physiotherapy }\end{array}$ & $8 / 24$ & 42 & $\begin{array}{l}\text { Review with } \\
\text { APP }\end{array}$ \\
\hline Martha, 54, F & $\begin{array}{c}\text { Teaching assistant; returned } \\
\text { on light duties }\end{array}$ & $\begin{array}{l}\text { Leg pain, } \\
\text { foot cramps, } \\
\text { numbness, } \\
\text { and } \\
\text { paraesthesia }\end{array}$ & 4 months & Improving & None & $\begin{array}{l}\text { Medication, } \\
\text { osteopathy, } \\
\text { physiotherapy }\end{array}$ & $10 / 24$ & 38 & Physiotherapy \\
\hline Hannah, 45, F & $\begin{array}{l}\text { Healthcare support worker; } \\
\text { returned on reduced hours }\end{array}$ & $\begin{array}{l}\text { Leg pain, foot } \\
\text { paraesthesia, } \\
\text { and cramps }\end{array}$ & 9 months & $\begin{array}{l}\text { Severe, } \\
\text { constant, not } \\
\text { changing }\end{array}$ & MRI & $\begin{array}{l}\text { Medication, } \\
\text { massage } \\
\text { therapy, } \\
\text { physiotherapy }\end{array}$ & $15 / 24$ & 51 & $\begin{array}{l}\text { Nerve root } \\
\text { block }\end{array}$ \\
\hline
\end{tabular}

$\mathrm{APP}=$ advanced physiotherapy practitioner. MRI = magnetic resonance imaging. RMDQ $=$ Modified Rolland Morris Disability Questionnaire. ${ }^{29} \mathrm{TSK}=$ Tampa Scale of Kinesiophobia ( $>37$ high score, and $\leq 37$ low scores). ${ }^{28} \mathrm{XR}=\mathrm{X}$-ray.

' $>$ ' indicates patient's relative rating of pain; for example, leg pain rated to be greater than back pain. 
Box 2 Participant themes and subthemes

\begin{tabular}{|c|c|}
\hline Theme & Subtheme within narrative \\
\hline Illness experience & $\begin{array}{l}\text { - Severe, unpredictable pain } \\
\text { - Mentally and physically draining } \\
\text { - Pain not 'visible' }\end{array}$ \\
\hline Concept of sciatica & $\begin{array}{l}\text { - Nerves 'tapped' or 'rubbed' by a 'swollen' disc } \\
\text { - Confusion over role of posture, alignment, and leg length } \\
\text { - A disc might 'shrink' with time } \\
\text { - Compression needs to be resolved for pain to improve } \\
\text { - Confirmation of compression on MRI gives 'validity' to suffering } \\
\text { - Absence of compression results in frustration and a lack of validation }\end{array}$ \\
\hline Treatment beliefs & $\begin{array}{l}\text { Exercise: Helpful to 'cope', but does not address compression } \\
\text { - Weightlifting, bending, and impact might increase size of the disc or } \\
\text { - Srevent it 'shrinking' } \\
\text { 'prength, swimming, yoga, stretching, and cycling improves 'health' and } \\
\text { - Warm-up improves elasticity of nerve and spinal tissues } \\
\text { - Stretching 'loosens up' the nerve, or 'pulls it clear' } \\
\text { Manual therapies: 'Realigns' the spine, 'frees up' nerves, but does not address } \\
\text { compression } \\
\text { - Massage helpful in managing symptoms } \\
\text { - Acupuncture possibly helpful, but not credible } \\
\text { Medication and nerve root block: Temporary treatments, not a 'fix' } \\
\text { - Nerve root block works by 'shrinking' the disc, or improving the nerve } \\
\text { 'route' } \\
\text { Surgery: A powerful, definitive treatment; 'fixes' compression } \\
\text { - Higher risk }\end{array}$ \\
\hline Desire for credible information & $\begin{array}{l}\text { - Seeking of information from a variety of sources } \\
\text { - Concern over credibility of information } \\
\text { - Clear explanations were highly valued } \\
\text { - Using a plastic model and MRI 'explains' the compression }\end{array}$ \\
\hline
\end{tabular}

\section{Results}

Thirteen participants were recruited, aged 21-76 years (median 53 years), with symptom duration ranging from 4 months to 40 years (median 9 months). Full participant characteristics are described in Table 1. The interview duration ranged from 33-64 minutes (median 45 minutes). Results include illustrative quotes with pseudonyms.

\section{Summary}

Four major themes were generated: (1) the illness experience, (2) the concept of sciatica, (3) treatment beliefs, and (4) the desire for credible information (see Box 2 for summary).

\section{Theme 1: The illness experience}

Participants emphasised the severity and unpredictability of the pain experience, which was 'mentally and physically draining':

'... it was absolutely excruciating. I felt like ten knives were being rammed into my body. It was horrendous. It took me completely by surprise.'

(Maria, 63, F)

Three participants expressed suicidal thoughts:

'[...] it's like I'm constantly in excruciating pain. The idea of living to old age in this level of pain almost feels like it's not an option. I've had, I guess you could consider, suicidal thoughts.'

(Megan, 21, F)

Participants felt like their pain was not 'visible' and therefore not taken seriously: 
'I feel like people have got no understanding of just how painful it can be. I don't think it's taken seriously enough. I don't think people release just how painful it is. It is excruciating pain, constant.'

(Maria, 63, F)

\section{Theme 2: The concept of 'sciatica'}

All participants described a concept of 'sciatica' in terms of discs being 'out of place' or 'swollen', causing either 'trapping' or 'rubbing' of sensitive neural tissue:

'[...] it's getting fouled somehow. It's getting rubbed. Aggravated. I don't necessarily think it's gonna be trapped, it's being irritated [...] '

(Gordon, 57, M)

If inflammation was considered, it was in terms of 'swelling', occupying more space and contributing to compression. No participant reported incorporating ischaemic mechanisms within their illness construct:

'The way I understand it is my disc is inflamed so it's bulging, so it's bigger than normal, and that's why it's pressing.'

(Gethin, 42, M)

Only one participant conceptualised inflammation as sensitising neural tissue. This participant had discussed his diagnosis with a close friend who was a physiotherapist working in elite sport. This suggests that credible information was capable of refining the illness construct for this individual:

"I believe there was two things happening: one, the actual pressure of the nerve itself, but two, it was a chemical reaction [...] those chemicals [...] they have a burning effect, corrosive effect, and it can be very damaging."

(Marley, 52, M)

There was confusion over the role of posture, spinal alignment, and leg length, with participants receiving conflicting explanations:

'A sports masseur I went to, to check my alignment. He said my alignments were fine. And the physio told me my alignments were out. So, I kind of ... I don't think anybody really knows what they're doing, to be honest.'

(Hannah, 45, F)

Participants were aware of the possibility of a disc reducing in size with time, but were not sure if it would for them, how long this would take, or how this process takes place:

'I'm not sure you can change it, once a disc slipped. I don't know. I'm assuming you can't. I've read that they will eventually dry or shrivel or something and move back off the nerve.'

(Maria, 63, F)

Many participants were aware of the potential for improvements in both the size of a disc and in their pain, with improvement or deterioration in pain being determined by a corresponding change in compression:

'The discs are abnormal and they're bulging [...] if they're bulging, surely there's got to be a way of getting them back to normal and when they're back to normal I won't have that pain.'

(Megan, 21, F)

When an MRI confirmed a diagnosis, participants appreciated the scan making the pain 'visible', the apparent certainty of knowing what was causing their pain and the anticipation of treatment. 
'I feel like at least I've got an answer to the pain ... it was a bit of a relief knowing that at least

... they know the problem now, that something can be done about it.'

(Megan, 21, F)

When an MRI did not explain their symptoms, participants were left confused, frustrated, and wanting an explanation and validation of their painful experience:

'Why is one person having that pain, but the next person is quite happily skipping around with ... with no symptoms at all? It doesn't make sense.'

(Myfanwy, 53, F)

Many were disappointed that the investigation had not identified a clear solution to their suffering, and participants with episodic symptoms felt it was important to have an MRI during an episode to detect the change in shape of the disc. When clinicians explained MRI findings by comparing to published asymptomatic MRI data, some participants were left with conflicting thoughts:

'You're told that ... lots of people have a very similar picture and don't have any symptoms whatsoever. It's frustrating because, if you're in as much pain, it's your body telling you there's something very wrong and you need to adapt to it, because it's a protective mechanism. Um, so it's sort of fighting against the two ideas.'

(Myfanwy, 53, F)

Participants appreciated the reassuring explanations they were given, even if they were not explained in terms that were easy to understand:

'I found some of the images quite difficult to follow. I didn't want to ask too many questions. She made it seem that it wasn't that serious, so I took her word for it. It was her tone of voice, really.'

(Patricia, 68, F)

While participants were constructing a concept of sciatica, healthcare practitioners seemed to have been influential in its development, often using a plastic model of the spine:

'You've got the model of vertebrae and things like that ... they were explaining that you've got your shock absorbers in-between the vertebrae there and mine are gone at the bottom, so I've got bone-on-bone which is trapping nerves and parts of my shock absorber stick out where they shouldn't be, so they then hit the nerves [...]'

(Harry, 44, M)

\section{Theme 3: The link between illness beliefs and treatment beliefs}

\section{Exercise}

Exercise such as swimming, yoga, stretching, and cycling was viewed as being helpful to improve spinal 'health' and to 'cope' with symptoms, but not capable of changing the compression. There was a desire for a well-structured rehabilitation programme which was flexible enough to deliver individualised treatment in a group exercise setting and was overseen by a 'credible' person. Participants wanted a clear plan for support if exercises caused an increase in pain. Individualised rehabilitation was seen as important as some participants could not tolerate sitting on a cycling seat, some could not sit down in a chair for long, and others could not stand for long. There was a concern that weightlifting or repetitive bending and/or impact might increase size of the disc or prevent it 'shrinking':

'I should imagine a lot of exercise ... would be unsafe. You're in danger of making things worse.

I wouldn't want to push that disc any further than it is. I'm hoping it's going back or shrivelling up.'

(Maria, 63, F)

Several participants had been advised against running by healthcare practitioners. Conversely, strengthening the spine was 'protective' of future episodes. Adequate warm-up was perceived to 
improve the elasticity of nerve and surrounding spinal tissues, with stretching afterwards helpful to 'loosen up' the nerve, or 'pull it clear' from the compression:

'Well, if you've got something that's slack, there's more chance it's gonna 'foul' on something. I look at it like a piece of rope and if you pull that tight, hopefully it'll make it clear.'

(Gordon, 57, M)

\section{Manual therapies}

Participants reported that manual treatment was explained by practitioners as working via 'realigning' the spine and 'freeing up' nerves, but participants felt it was not capable of changing the cause of the compression:

'First of all, I saw a chiropractor because I thought there was gonna be a simple solution of some form of manipulation that was gonna, sort of, realign whatever was going on.'

(Gethin, 42, M)

Participants felt that soft-tissue massage was helpful in managing symptoms, and acupuncture might be helpful, but lacked credibility.

\section{Medication}

While there was a strong desire for effective pain control, participants expressed concerns over effectiveness, side effects, and the potential for addiction with medications. Participants viewed medication as a short-term treatment that did not address the underlying cause:

'[...] the ibuprofen was never gonna work on a bit of my disc protruding into that area, how I was hoping it was gonna do anything about that, I'm not so sure [...] Don't put a plaster on it, just get in there and sort this.'

(Harry, 44, M)

\section{Nerve root block}

A nerve root block (NRB) was also seen as a short-term treatment option that worked by reducing compression:

'I'm assuming the injection would reduce the inflammation [...] then it would reduce it [the disc] to the point that it's not touching on the nerve [...] but my view on it was once that wears off, the bulge will start coming back and then it'll go back into it.'

(Gethin, 42, M)

There was considerable uncertainty and confusion about how a nerve root injection might work. One participant misunderstood the term 'root' to mean 'route', which had not been clarified, and this impacted on how they viewed its mechanism of action:

'It's a cortisone injection, route [sic] nerve block. By those words, I've got a nerve and there's a route going down there and it gets blocked [...] and that's gonna try and take the spasm or swelling or anything that's around my disc, and hopefully that should make the whole route clearer.'

(Marley, 52, M)

Surgery

Surgery was perceived as involving higher risks, but was seen as taking decisive, definitive action that addressed the underlying problem:

'The way it's been explained to me is that [...] the discs are abnormal and they're bulging. So that if they're bulging, surely there's got to be a way of getting them back to normal and when they're back to normal I won't have that pain [...] '

(Megan, 21, F) 
'The process of the disc damage. I think once you've got it, I think the operation is the only solution.'

(Harry, 44, M)

\section{Theme 4: The desire for credible information}

Explanations for their pain were highly valued by participants, and there was a desire for early access to credible sources of information to conceptualise their illness:

' [...] if I just know myself what's going on [...] , I could probably deal with it myself just as effectively as taking half a day off work to go and sit at the GP surgery to get given ibuprofen or some other tranquiliser that I don't really want to take.'

(Harry, 44, M)

As well as asking healthcare practitioners, participants also searched for information from other sources (such as books, newpapers, social media, websites, and forums). There was a concern that the search for information could easily become obsessive and incorrect information could be unhelpful. When searching for information, participants were mindful of conflicting commercial interests and unrealistic expectations, but remained curious:

'I really found it difficult to access [websites] that I thought, "They're not trying to sell me something here." '

(Harry, 44, M)

Several participants suggested ways to improve access to credible information for patients:

'If there is a video on sciatica and what exactly it is and how it's caused, surely a short video or something like this, go to YouTube [...] , you could learn everything, exactly what's going on.'

(Marley, 52, M)

\section{Discussion}

\section{Summary}

This study explored how people rationalise their painful experiences after being diagnosed with LRP. This is the first study to explore illness representations in this population. Four main themes were identified which describe the development of an explanatory construct: (1) the devastating experience requiring an explanation; (2) the illness identities that people construct; (3) the impact of the illness identity on treatment beliefs; and 4) an ongoing search for further credible information to refine their illness identity.

\section{Strengths and limitations}

Participants were recruited from a single site, thus limiting transferability, although findings are consistent with previously published data in this field.

The unavoidable influence of the researcher's position on the data collected is acknowledged. Several steps were taken to maintain reflexivity and limit bias throughout data collection (as detailed in the Method section). The use of a single analyst and data coder was mitigated by regular discussion with the supervisory team to ensure transparency and integrity of the analysis.

\section{Comparisons with existing literature}

Consistent with previous studies, participants reported a range of symptoms that were physically and mentally draining, ${ }^{16}$ and feeling like they were not taken seriously ${ }^{36}$ as their symptoms were underappreciated, illegitimate, and invisible.

Three participants expressed current or previous suicidal ideation, which confirms previous findings. ${ }^{36}$ The unpredictability of sudden and severe pain episodes led to feelings of anxiety, dread, and despair, which is consistent with experimental evidence. ${ }^{37}$ 
Participants valued clear information on their diagnosis and appreciated the use of plastic models of the spine to help explanations. As with previous findings, ${ }^{38}$ this study found participants also highly valued clinicians taking the time to show them their MRI scan. It is likely that the use of plastic models and visualisation of MRI will have influenced the illness construct of participants. A diagnosis helped participants to either manage ongoing symptoms with a sense of certainty, or to look forward to a definitive treatment. Similar to previous studies, there was a desire for a clear prognosis. ${ }^{16,38}$ In contrast to previous work, ${ }^{38}$ this study did not find concern of serious pathology (such as malignancy).

In agreement with previous findings, ${ }^{38}$ this study found that when an MRI failed to adequately explain their experience, participants were left feeling invalidated, frustrated, and confused. The absence of compression on MRI was in direct conflict with their existing illness identity, leading to a distressing and confusing process of trying to construct a new one. None of these participants had been able to construct new meaningful identities to explain their ongoing symptoms.

The illness constructs appeared to have influenced beliefs regarding treatment effectiveness. Treatments addressing compression (such as surgery) were easily understood and perceived as having more control over the condition. Those treatments seeking to address inflammatory or neuropathic mechanisms (such as medication or NRB) were confusing and therefore perceived as less powerful. Despite being perceived as lacking control over compression, there was a clear desire for structured conservative management.

Participants expressed a desire for credible information as it was an important step in understanding their illness before considering treatment. As well as information from healthcare clinicians and social networks, participants gathered information from a variety of written media sources including newspapers, online forums, social media, and textbooks. Much of this information was from commercial companies advertising products and services. Some participants expressed concern over the credibility of the information, and scepticism of conflicting commercial interests, but were not clear how to select credible sources. Participants expressed a preference for visual, online information to support their decision-making.

\section{Implications for research and practice}

These findings highlight the importance of asking patients to explain their understanding of LRP. Clinicians should to consider providing broader explanations for LRP pathology that include inflammatory and neuropathic pain mechanisms (which appeared to be lacking). Clinicians should take care to include these mechanisms when explaining a diagnosis using plastic models of the spine. This may be especially important when a compressive explanation is not conclusively demonstrated by MRI, as it will enable clinicians to validate and legitimise patients' symptoms. The authors recommend caution when comparing MRIs of symptomatic versus asymptomatic patients, as this may have unintended delegitimising effects. They also agree with previous calls for accurate information-sharing regarding prognosis and prompt access to treatment, including psychological support.

Further research is required to understand the most effective type of interventions that support the development of accurate conceptual models for LRP. For example, including ischaemic mechanisms as part of an explanation of pathology may broaden a patient's understanding, but the effect on behaviour and decision-making is unknown. Identifying the optimal content, context, and timing of interventions is likely to be important. Researchers should consider important outcomes such as patient satisfaction with decision-making, pain self-efficacy, and treatment expectations.

This is the first study to specifically explore illness constructs in an LRP population. It has confirmed the overwhelming impact of LRP, which drives the individual to construct an illness identity to conceptualise their suffering. Illness identities were firmly entrenched in a mechanical-compressive model that did not incorporate inflammatory, ischaemic, and neuropathic pain mechanisms. Consistent with the CSM, information from a variety of sources appeared to become interwoven with advice from healthcare clinicians to form and refine these illness identities. These findings have identified several opportunities to help patients construct more accurate illness identities, providing validation to those who need it and a clear foundation for shared decision-making.

\section{Funding}

This research and the preparation of the manuscript was supported by a First into Research Fellowship from Research Capacity Building Collaboration, Wales. The authors gratefully acknowledge additional funding for qualitative research training provided by a research award from the Musculo- 
skeletal Association of Chartered Physiotherapists.

Ethical approval

Ethical approval was gained from the South East Welsh Research Ethics Committee for the overarching study exploring illness and treatment beliefs in a lumbar radicular pain population (reference number: 17/WA/0363) in November 2017.

Provenance

Freely submitted; externally peer reviewed.

\section{Acknowledgments}

The authors gratefully acknowledge the generous contribution of participants and patient representatives involved in this study.

\section{References}

1. Konstantinou $\mathrm{K}$, Hider $\mathrm{SL}$, Jordan $\mathrm{JL}$, et al. The impact of low back-related leg pain on outcomes as compared with low back pain alone: a systematic review of the literature. Clin J Pain 2013; 29(7): 644-654. DOI: https://doi.org/10. 1097/AJP.0b013e31826f9a52

2. Koes BW, van Tulder MW, Peul WC. Diagnosis and treatment of sciatica. BMJ 2007; 334(7607): 1313-1317. DOI: https://doi.org/10.1136/bmj.39223.428495.BE

3. van Rijn JC, Klemetso N, Reitsma JB, et al. Symptomatic and asymptomatic abnormalities in patients with lumbosacral radicular syndrome: clinical examination compared with MRI. Clin Neurol Neurosurg 2006; 108(6): 553-557. DOI: https://doi.org/10.1016/j.clineuro.2005.10.003

4. Suri P, Boyko EJ, Goldberg J, et al. Longitudinal associations between incident lumbar spine MRI findings and chronic low back pain or radicular symptoms: retrospective analysis of data from the longitudinal assessment of imaging and disability of the back (LAIDBACK). BMC Musculoskelet Disord 2014; 15(1): 152. DOI: https://doi.org/ 10.1186/1471-2474-15-152

5. Karppinen J, Malmivaara A, Tervonen $\mathrm{O}$, et al. Severity of symptoms and signs in relation to magnetic resonance imaging findings among sciatic patients. Spine (Phila Pa 1976) 2001; 26(7): E149-E154. DOI: https://doi.org/10. 1097/00007632-200104010-00015

6. el Barzouhi A, Vleggeert-Lankamp CLAM, Lycklama à Nijeholt GJ, et al. Influence of low back pain and prognostic value of MRI in sciatica patients in relation to back pain. PLoS One 2014; 9(3): e90800. DOI: https://doi.org/10. 1371/journal.pone.0090800

7. Konstantinou K, Dunn KM, Ogollah R, et al. Prognosis of sciatica and back-related leg pain in primary care: the ATLAS cohort. Spine J 2018; 18(6): 1030-1040. DOI: https://doi.org/10.1016/j.spinee.2017.10.071

8. Zhong M, Liu J-T, Jiang $\mathrm{H}$, et al. Incidence of spontaneous resorption of lumbar disc herniation: a meta-analysis. Pain Physician 2017; 20(1): E45-52.

9. de Souza Grava AL, Ferrari LF, Defino HLA. Cytokine inhibition and time-related influence of inflammatory stimuli on the hyperalgesia induced by the nucleus pulposus. Eur Spine J 2012; 21(3): 537-545. DOI: https://doi.org/10. 1007/s00586-011-2027-8

10. Albrecht DS, Ahmed SU, Kettner NW, et al. Neuroinflammation of the spinal cord and nerve roots in chronic radicular pain patients. Pain 2018; 159(5): 968-977. DOI: https://doi.org/10.1097/j.pain.0000000000001171

11. Kuslich SD, Ulstrom CL, Michael CJ. The tissue origin of low back pain and sciatica: a report of pain response to tissue stimulation during operations on the lumbar spine using local anesthesia. Orthop Clin North Am 1991; 22(2): 181-187.

12. Peng B, Wu W, Li Z, et al. Chemical radiculitis. Pain 2007; 127(1-2): 11-16. DOI: https://doi.org/10.1016/j.pain. 2006.06.034

13. Marshall LL, Trethewie ER, Curtain CC. Chemical radiculitis. A clinical, physiological and immunological study. Clin Orthop Relat Res 1977; 129(129): 61-67.

14. Lin J-H, Chiang H-Y, Chen C-C. Lumbar radiculopathy and its neurobiological basis. WJA 2014; 3(2): 162-173. DOI: https://doi.org/10.5313/wja.v3.i2.162

15. Weber $\mathrm{H}, \mathrm{Holme} \mathrm{I}$, Amlie $\mathrm{E}$. The natural course of acute sciatica with nerve root symptoms in a double-blind placebo-controlled trial evaluating the effect of piroxicam. Spine (Phila Pa 1976) 1993; 18(11): 1433-1438. DOI: https://doi.org/10.1097/00007632-199309010-00006

16. Ong BN, Konstantinou K, Corbett $\mathrm{M}$, et al. Patients' own accounts of sciatica: a qualitative study. Spine (Phila Pa 1976) 2011; 36(15): 1251-1256. DOI: https://doi.org/10.1097/BRS.0b013e318204f7a2

17. Leventhal H, Phillips LA, Burns E. The Common-Sense Model of self-regulation (CSM): a dynamic framework for understanding illness self-management. J Behav Med 2016; 39(6): 935-946. DOI: https://doi.org/10.1007/s10865016-9782-2

18. McCluskey S, Brooks J, King N, Burton K. The influence of 'significant others' on persistent back pain and work participation: a qualitative exploration of illness perceptions. BMC Musculoskelet Disord 2011; 12(1): 236. DOI: https://doi.org/10.1186/1471-2474-12-236 
19. van Bekkum JE, Hilton S. Primary care nurses' experiences of how the mass media influence frontline healthcare in the UK. BMC Fam Pract 2013; 14(1): 178. DOI: https://doi.org/10.1186/1471-2296-14-178

20. Knowles SR, Nelson EA, Castle DJ, et al. Using the common sense model of illness to examine interrelationships between symptom severity and health outcomes in end-stage osteoarthritis patients. Rheumatology (Oxford) 2016; 55(6): 1066-1073. DOI: https://doi.org/10.1093/rheumatology/kew022

21. Clarke AL, Yates T, Smith AC, Chilcot J. Patient's perceptions of chronic kidney disease and their association with psychosocial and clinical outcomes: a narrative review. Clin Kidney J 2016; 9(3): 494-502. DOI: https://doi.org/10. 1093/ckj/sfw014

22. Dima A, Lewith GT, Little P, et al. Patients' treatment beliefs in low back pain: development and validation of a questionnaire in primary care. Pain 2015; 156(8): 1489-1500. DOI: https://doi.org/10.1097/j.pain. 0000000000000193

23. Aujla N, Walker M, Sprigg N, et al. Can illness beliefs, from the common-sense model, prospectively predict adherence to self-management behaviours? A systematic review and meta-analysis. Psychol Health 2016; 31(8): 931-958. DOI: https://doi.org/10.1080/08870446.2016.1153640

24. Welsh Assembly Government. StatsWales: Population estimates by local health boards and age. 2017; https:// statswales.gov.wales/Catalogue/Population-and-Migration/Population/Estimates/Local-Health-Boards/ populationestimates-by-lhb-age (accessed 24 Jul 2019).

25. Merskey H, Bogduk N. Classification of chronic pain: Descriptions of chronic pain syndromes and definitions of pain terms. 2nd edn. Seattle: IASP Press; 1994.

26. Kongsted A, Kent $\mathrm{P}$, Albert $\mathrm{H}$, et al. Patients with low back pain differ from those who also have leg pain or signs of nerve root involvement - a cross-sectional study. BMC Musculoskelet Disord 2012; 13(1): 236. DOI: https://doi. org/10.1186/1471-2474-13-236

27. Weinman J, Petrie KJ, Moss-morris R, et al. The illness perception questionnaire: a new method for assessing the cognitive representation of illness. Psychol Health 1996; 11(3): 431-445. DOI: https://doi.org/10.1080/ 08870449608400270

28. Lundberg MKE, Styf J, Carlsson SG. A psychometric evaluation of the Tampa scale for Kinesiophobia - from a physiotherapeutic perspective. Physiother Theory Pract 2004; 20(2): 121-133. DOI: https://doi.org/10.1080/ 09593980490453002

29. Kim M, Guilfoyle MR, Seeley HM, Laing RJ. A modified Roland-Morris disability scale for the assessment of sciatica. Acta Neurochir (Wien) 2010; 152(9): 1549-1553. DOI: https://doi.org/10.1007/s00701-010-0679-5

30. Foster NE, Bishop A, Thomas E, et al. Illness perceptions of low back pain patients in primary care: what are they, do they change and are they associated with outcome? Pain 2008; 136(1-2): 177-187. DOI: https://doi.org/10. 1016/j.pain.2007.12.007

31. Bunzli S, Smith A, Schütze R, O'Sullivan P. Beliefs underlying pain-related fear and how they evolve: a qualitative investigation in people with chronic back pain and high pain-related fear. BMJ Open 2015; 5(10): e008847. DOI: https://doi.org/10.1136/bmjopen-2015-008847

32. Lincoln YS, Guba EG, Pilotta JJ. Naturalistic inquiry. Beverly Hills: Sage Publications; 1985. 438-439. DOI: https:// doi.org/10.1016/0147-1767(85)90062-8 33

33. Malterud K, Siersma VD, Guassora AD. Sample size in qualitative interview studies: guided by information power. Qual Health Res 2016; 26(13): 1753-1760. DOI: https://doi.org/10.1177/1049732315617444

34. King N, Symon G. Using templates in the thematic analysis of text. In: Cassell C, Symon G, eds. Essential guide to qualitative methods in organizational research. London: SAGE Publications; 2004. 256-270.

35. Ziebland S, McPherson A. Making sense of qualitative data analysis: an introduction with illustrations from DIPEx (personal experiences of health and illness. Med Educ 2006; 40(5): 405-414. DOI: https://doi.org/10.1111/j.13652929.2006.02467.x

36. Ryan C, Roberts L. 'Life on hold': the lived experience of radicular symptoms. A qualitative, interpretative inquiry. Musculoskelet Sci Pract 2019; 39: 51-57. DOI: https://doi.org/10.1016/j.msksp.2018.11.005

37. Huang Y, Shang Q, Dai S, Ma Q. Dread of uncertain pain: an event-related potential study. PLoS One 2017; 12(8): e0182489. DOI: https://doi.org/10.1371/journal.pone.0182489

38. Ryan C, Roberts LC. Investigations for radiculopathy: the patient perspective. A qualitative, interpretative inquiry. Musculoskelet Sci Pract 2018; 33: 71-76. DOI: https://doi.org/10.1016/j.msksp.2017.11.005 